\title{
ВИДОВОЕ РАЗНООБРАЗИЕ ФИТОЦЕНОЗОВ ПРИ ПРОВЕДЕНИИ ИНЖЕНЕРНО-ЭКОЛОГИЧЕСКИХ ИССЛЕДОВАНИЙ НА ЮГЕ О. КУНАШИР
}

\section{SPECIES DIVERSITY OF PHYTOCENOSES DURING ENGINEERING AND ENVIRONMENTAL SURVEYS IN THE SOUTH OF THE ISLAND. KUNASHIR}

\author{
Ya. Popova \\ Ya. Denisova
}

Summary. The article describes the characteristics of the vegetation cover during scientific ecological surveys of the site located in the south of the island of Kunashir with the aim of preserving and rational use of phytocenoses. In the studied phytocenoses (spruce-shrub-forb community, shrub-cotton grass-sedge-forb community with excessive moisture) 29 grows. Species of vascular plants. In the study area, 4 rare plant species, listed in the Red Data Books of the Russian Federation and the Sakhalin Region, were identified, such as Picea glehnii (Fr. Schmidt) Mast., Iris ensata Thunb., Pogonia japonica Reichenb. fil., Ilex sugerokii Maxim.

Keywords: plant communities; phytocenosis; rare plant species; Kunashir island; engineering and environmental studies

\section{Введение}

$\mathbf{H}$ ачинаниелюбойхозяйственнойдеятельноститребует проведение инженерных изысканий на исследуемой территории. Для сохранения и рационального использования биологического разнообразия, а также изучения природных условий и ландшафтов района, необходимо проведение инженерно-экологических исследований. Нами была дана характеристика растительного покрова проектируемого участка, который расположен на территории острова Кунашир. Для решения поставленных задач, были выполнены полевые маршрутные исследования, а затем камеральная обработка собранных материалов.

\section{Материалы и метолы}

Исследования проводились в вегетационный сезон 2017 г. Описание растительности выполнялось по методикам, применяемыми в геоботанике (Шенников, 1964; и др.), лесоведении (Сукачев, Зонн, 1961; Мелехов, 2002) $[8,11,12]$. Обилие растений фитоценозов опреде-
Попова Яна Павловна

К.г.н., дочент, ФГБОУ ВО «Сахалинский государственный университет»

yana-b@inbox.ru

Денисова Янина Вячеславовна

К.б.н., доцент, ФГБОУВО «Сахалинский государственный университет» deyan4@mail.ru

Аннотация. В статье дана характеристика растительного покрова при проведении научных экологических изысканий участка, расположенного на территории юга острова Кунашир, с целью сохранения и рационального использования фитоценозов. В исследуемых фитоценозах (елово-кустарниково-разнотравное сообщество, кустарниково-пушицево-осоково-разнотравное сообщество с избыточным увлажнением) произрастает 29 видов сосудистых растений. На исследуемой территории выявлено 4 редких вида растений, занесенных в Красные книги РФ и Сахалинской области, такие как Picea glehnii (Fr. Schmidt) Mast., Iris ensata Thunb., Pogonia japonica Reichenb. fil., llex sugerokii Maxim.

Ключевые слова: растительные сообщества; фитоценоз; редкие виды растений; остров Кунашир; инженерно-экологические исследования.

ляли по шкале Друде, высоту деревьев измеряли высотомером, а диаметр их - мерной вилкой. Установление таксономического статуса сосудистых растений проводилось по региональным определителям (Определитель, 1974; Баркалов, 2009) [2,9] с уточнением названий видов, по многотомным сведениям, «Сосудистые растения Советского Дальнего Востока» (1985-1996) [10] и др.

\section{^итературный обзор}

Изучению природных комплексов острова Кунашир, в том числе его флористического состава посвящены работы ряда авторов (Воробьев, 1963; Баркалов, 2009; Еременко, Баркалов, 2010) [2,4,5].

По характеру растительного покрова и распространению отдельных видов Южные Курилы делятся на два флористических района, из них остров Кунашир входит в состав Южнокурильского района, а острова Малой Курильской гряды - Малокурильского района Южнокурильско-Хоккайдского округа Сахалино-Хоккайдской 


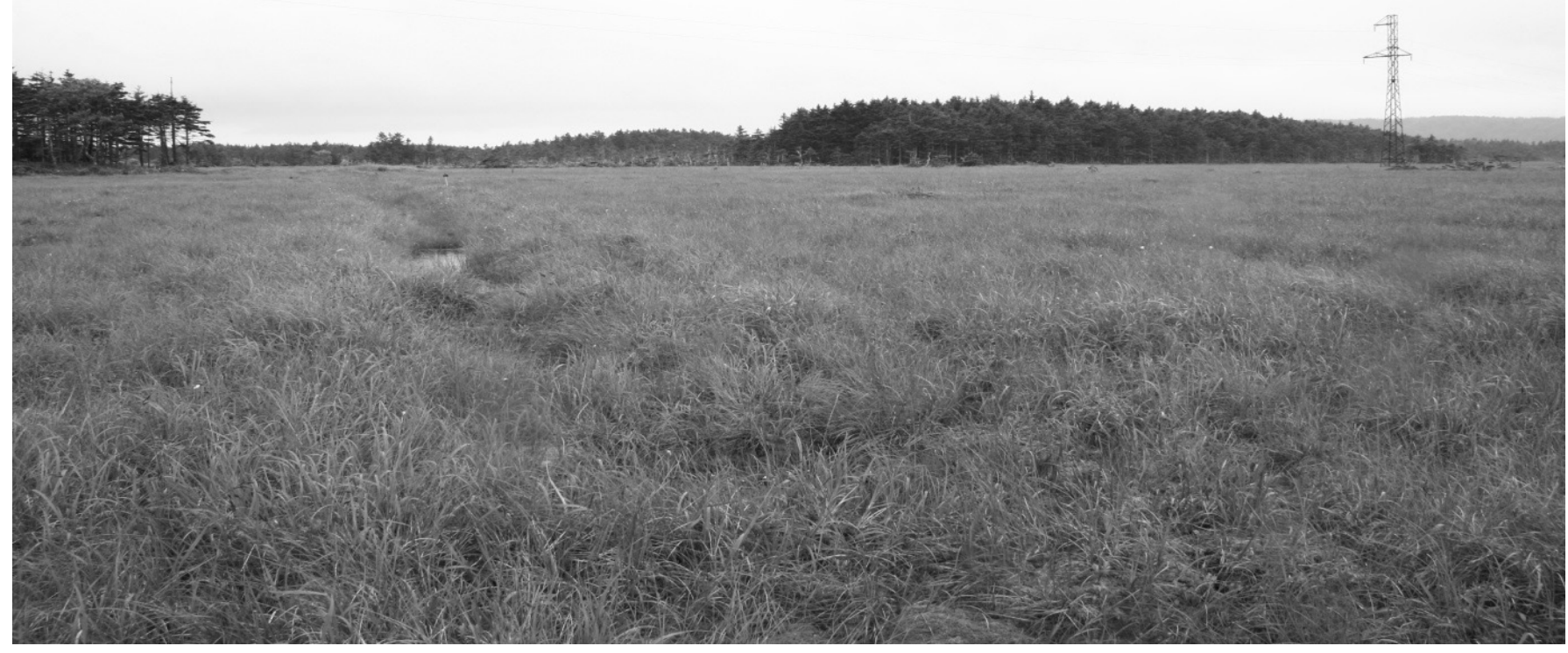

Рис. 1. Район исследования

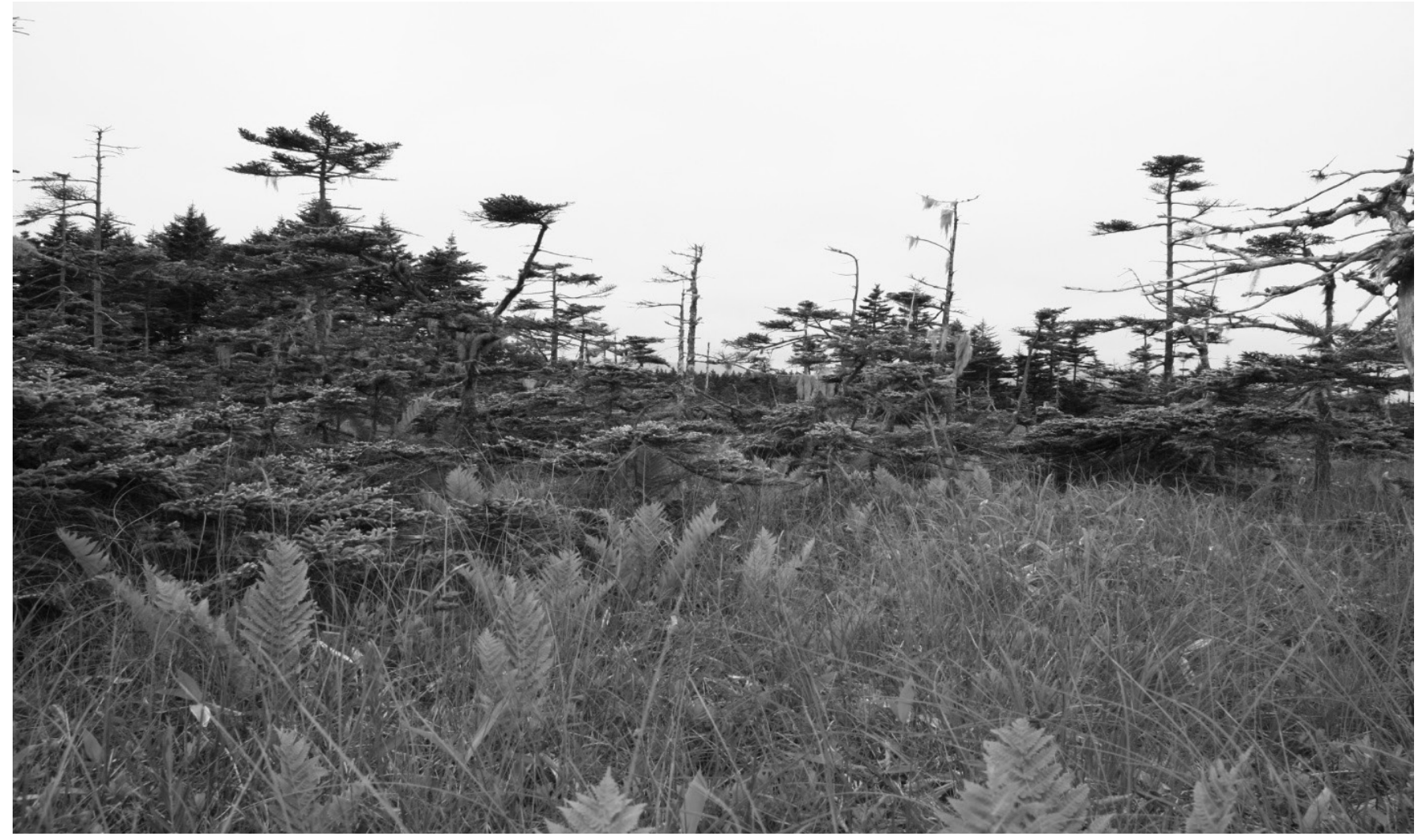

Рис. 2. Елово-кустарниково-разнотравное сообщество (Picea glehnii - Myrica tomentosa+llex sugerokii+Ledum palustriforme - Eriophorum vaginatum+Oxycoccus microcarpus+Carex sp.) 
Таблица 1. Краткая лесоводственно-таксационная характеристика древостоя

\begin{tabular}{|l|l|l|l|l|}
\hline № описания & Ярус & Состав древостоя & Высота, м & Диаметр, см \\
\hline 2 & I & $10 \mathrm{Eг}$ & 4 & 8 \\
\hline 3 & 1 & $10 \mathrm{Eг}$ & 3 & 6 \\
\hline
\end{tabular}

Примечание: Ег — Ель Глена

Таблица 2. Состав и обилие растений елово-кустарниково-разнотравного сообщества

\begin{tabular}{|c|c|c|}
\hline \multirow{2}{*}{ Название растений } & \multicolumn{2}{|c|}{ Обилие по сообществам (описаниям) } \\
\hline & 2 & 3 \\
\hline \multicolumn{3}{|l|}{ ДРЕВЕСНЫЙ ЯРУС } \\
\hline Picea glehnii & Sp & Sp \\
\hline \multicolumn{3}{|l|}{ КУСТАРНИКОВЫЙ ЯРУС } \\
\hline Pinus pumila & Sol & - \\
\hline Myrica tomentosa & Sp & Sp \\
\hline Ledum palustriforme & Sol & Sp \\
\hline Sasa kurilensis & $\mathrm{Sp}$ & - \\
\hline Vaccinium hirtum & Sol & - \\
\hline Ilex sugerokii & $\mathrm{Sp}$ & $\mathrm{Sp}$ \\
\hline Ilex crenata & Sol & - \\
\hline \multicolumn{3}{|c|}{ ТРАВЯНО-КУСТАРНИЧКОВЫЙ ЯРУС } \\
\hline Eriophorum vaginatum & $\mathrm{Sp}$ & $S p$ \\
\hline Oxycoccus microcarpus & Sol & Sol \\
\hline Osmundastrum asiaticum & Sol & - \\
\hline Lysichiton camtschatcense & Sol & Sol \\
\hline Empetrum sibiricum & Sol & Sol \\
\hline Coptis trifolia & Sol & - \\
\hline Drosera rotundifolia & Sol & Sol \\
\hline Lycopodium juniperoideum & Sol & - \\
\hline Lycopodium clavatum & Sol & - \\
\hline Carex sp. & cop1 & Sp \\
\hline \multicolumn{3}{|c|}{ МОХОВО-ЛИШАЙНИКОВЫЙ ПОКРОВ } \\
\hline Mxn & Sol & $\mathrm{Sp}$ \\
\hline Лишайники & Sol & Sp \\
\hline
\end{tabular}

провинции Восточноазиатской флористической области (Баркалов, 2009) [2].

Согласно геоботаническому районированию, южные Курильские острова относятся к Дальневосточной хвойно-широколиственной лесной области и особому
Курило-Сахалинскому округу Японо-Корейской океанической провинции (Воробьев, 1963) [4]. Это район темнохвойных и смешанных лесов с большим количеством южных элементов. Основу растительного покрова здесь, образуют представители охотоморской флоры при значительном участии элементов маньчжурского и особен- 
Таблица 3. Состав и обилие растений кустарниково-разнотравного сообщества

\begin{tabular}{|c|c|}
\hline \multirow{2}{*}{ Название растений } & Обилие по сообществам (описаниям) \\
\hline & 2 \\
\hline \multicolumn{2}{|l|}{ КУСТАРНИКОВЫЙ ЯРУС } \\
\hline Myrica tomentosa & Cop1 \\
\hline Ledum palustriforme & $S p$ \\
\hline Sasa kurilensis & Sol \\
\hline Ilex sugerokii & Sol \\
\hline \multicolumn{2}{|c|}{ ТРАВЯНО-КУСТАРНИЧКОВЫЙ ЯРУС } \\
\hline Iris ensata & Sol \\
\hline Hemerocallis esculenta & Sol \\
\hline Sieversia pentapetala & Cop1 \\
\hline Drosera anglica & Sol \\
\hline Drosera rotundifolia & $\mathrm{Sp}$ \\
\hline Eriophorum vaginatum & $\mathrm{Sp}$ \\
\hline Oxycoccus microcarpus & Cop1 \\
\hline Lysichiton camtschatcense & Sol \\
\hline Empetrum sibiricum & Sol \\
\hline Menyanthes trifoliate & Sol \\
\hline Utricularia intermedia & Sol \\
\hline Pogonia japonica & Sol \\
\hline Andromeda polifolia & Sol \\
\hline Lycopodium juniperoideum & Sol \\
\hline Carex sp. & $\mathrm{Sp}$ \\
\hline \multicolumn{2}{|c|}{ МОХОВО-ЛИШАЙНИКОВЫЙ ПОКРОВ } \\
\hline Мхи & Cop1 \\
\hline Лишайники & Sol \\
\hline
\end{tabular}

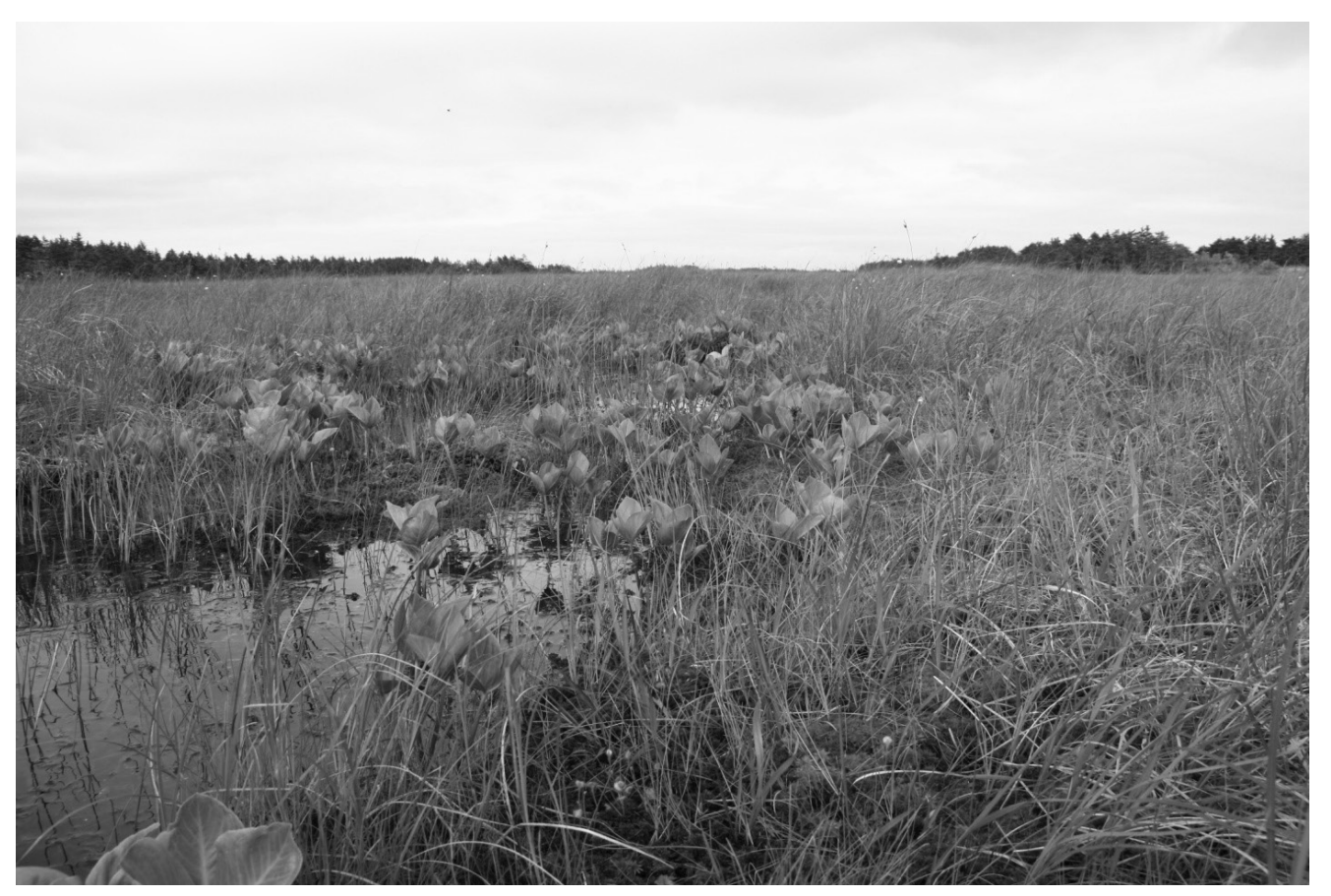

Рис. 3. Кустарничково-пушицево-осоково-разнотравное сообщество с избыточным увлажнением (Myrica tomentosa+llex sugerokii+Ledum palustriforme - Sieversia pentapetala+Drosera anglica+Drosera rotundifolia+Eriophorum vaginatum+Oxycoccus microcarpus+Carex sp.) 


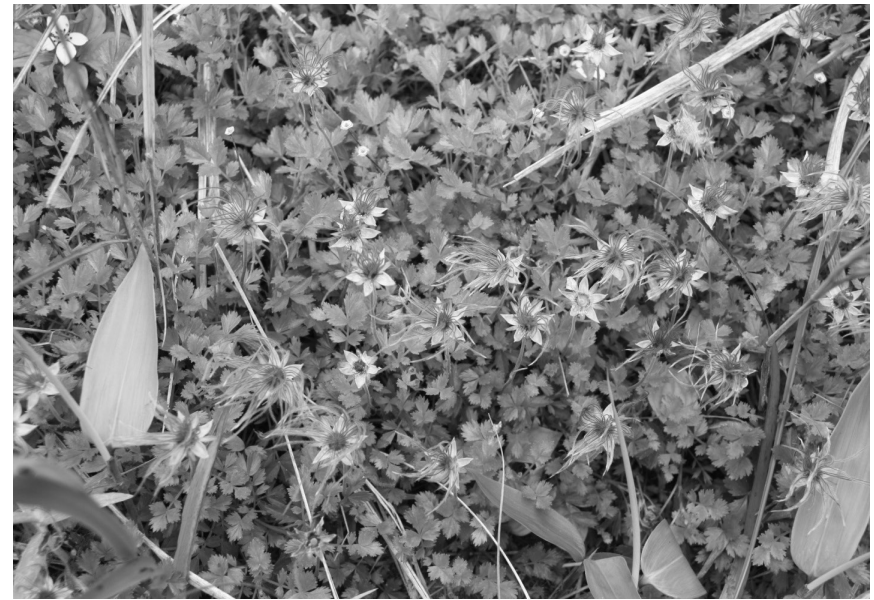

a

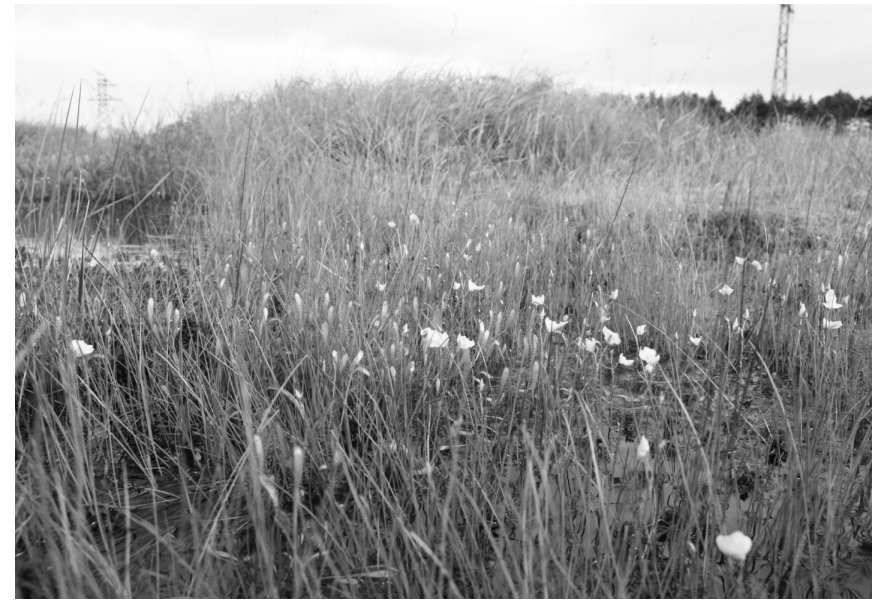

6

Pис. 4. Sieversia pentapetala (A), Drosera anglica, Utricularia intermedia (Б)

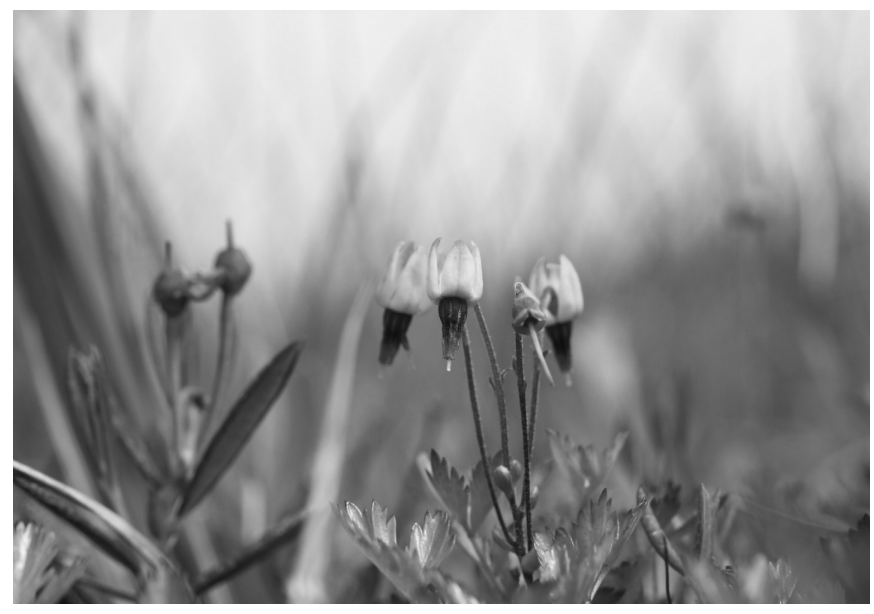

a

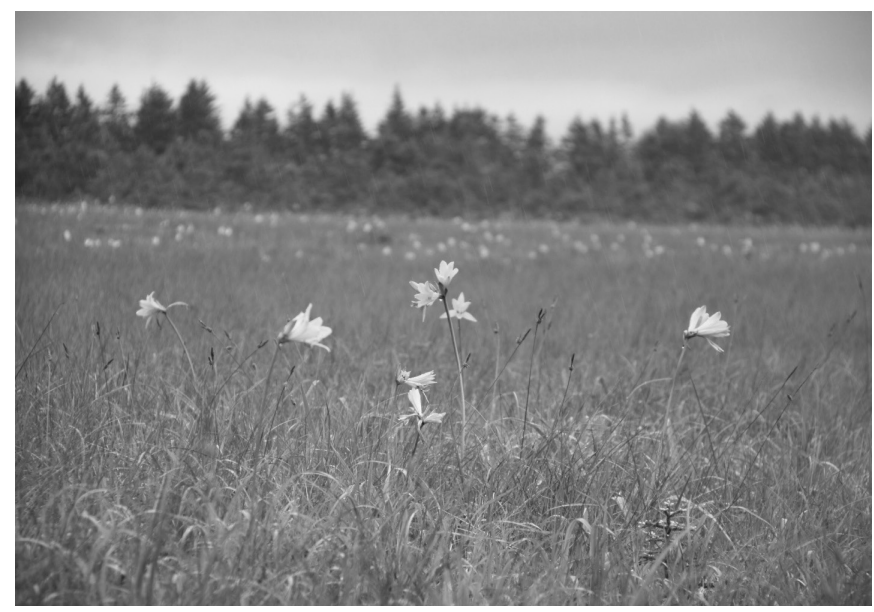

6

Pис. 5. Hemerocallis esculenta (A), Oxycoccus microcarpus (Б)

но северояпонского флористических комплексов (Еременко, Баркалов, 2010) [5].

Территория рассматриваемого геоботанического района, расположена на Южно-Курильском перешейке и проходит от поселка Южно-Курильск к озеру Серебряное (рис. 1) [1].

Наиболее распространенными типами растительных сообществ в районе исследования явились елово-кустарниково-разнотравное (Picea glehnii-Myrica tomentosa (DC.) Aschers. etGraebn. + Ilex sugerokii + Ledum palustriforme Khokhr. etMaz. - Eriophorum vaginatum L. + Oxycoccus microcarpus Turcz. exRupr. + Carex sp.) и кустарноково-разнотравное сообщество (Myrica tomentosa (DC.) Aschers. et Graebn. + Ilex sugerokii + Ledum palustriforme Khokhr. et
Maz. - Sieversia pentapetala (L.) Greene + Drosera anglica Huds. + Drosera rotundifolia L. + Eriophorum vaginatum L. + Oxycoccus microcarpus Turcz. ex Rupr. + Carex sp.).

Елово-кустарниково-разнотравное сообщество (Picea glehnii - Myrica tomentosa+Ilex sugerokii+Ledum palustriforme - Eriophorum vaginatum+Oxycoccus microcarpus+Carex sp.) имеет

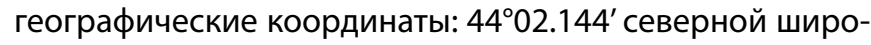
ты и $145^{\circ} 49.681^{\prime}$ восточной долготы. Высота над уровнем моря составляет 14 м. Размеры описываемой площади 10х15 м. Основной лесообразующей породой здесь выступает Picea glehnii (рис. 2).

Кустарниковый ярус в видовом отношении достаточно разнообразен, в основном включает такие виды, 
Таблица 4. Редкие виды растений Елово-кустарниково-разнотравного и Кустарниково-пушицевоосоково-разнотравного с избыточным увлажнением сообществ

\begin{tabular}{|c|c|c|c|c|}
\hline \multirow{2}{*}{ № п/п } & \multirow{2}{*}{ Виды } & \multicolumn{2}{|c|}{ Красные книга } & \multirow{2}{*}{ Статус } \\
\hline & & $P \Phi$ & Сахалинской области & \\
\hline 1 & Picea glehnii & - & + & $2(V)$ \\
\hline 2 & Iris ensata & + & + & $1(E)$ \\
\hline 3 & Pogonia japonica & + & + & $3(\mathrm{R})$ \\
\hline 4 & Ilex sugerokii & + & + & $2(\mathrm{~V})$ \\
\hline
\end{tabular}

Примечание: 1 (E) - виды, находящиеся под угрозой исчезновения; 2(V) - уязвимые виды,

сокращающие численность или ареал; $3(\mathrm{R})$ - редкие виды, представленные небольшими популяциями, которые в настоящее время не находятся под угрозой исчезновения и не являются уязвимыми, но вследствие своей редкости и малочисленности рискуют попасть в вышеназванные категории

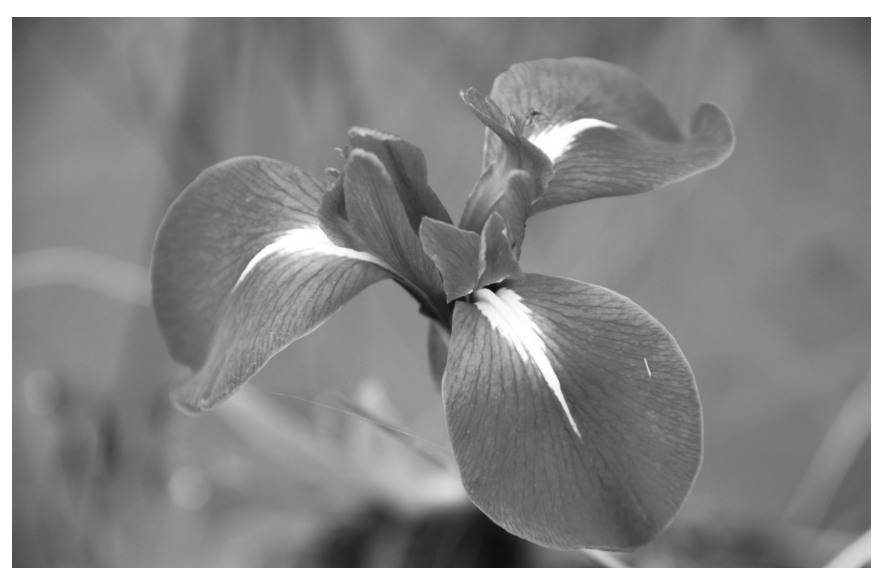

a

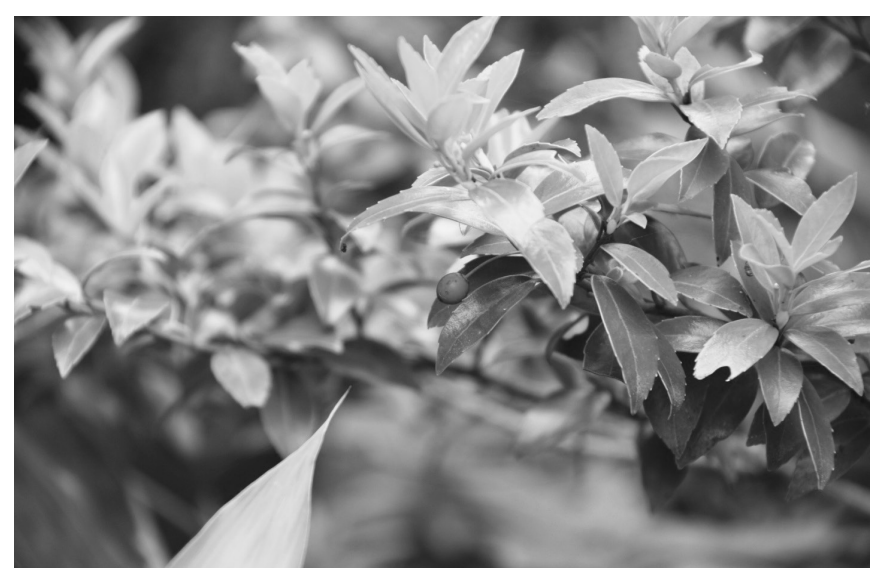

6

Pис. 6. Iris ensata (A), llex sugerokii (Б)

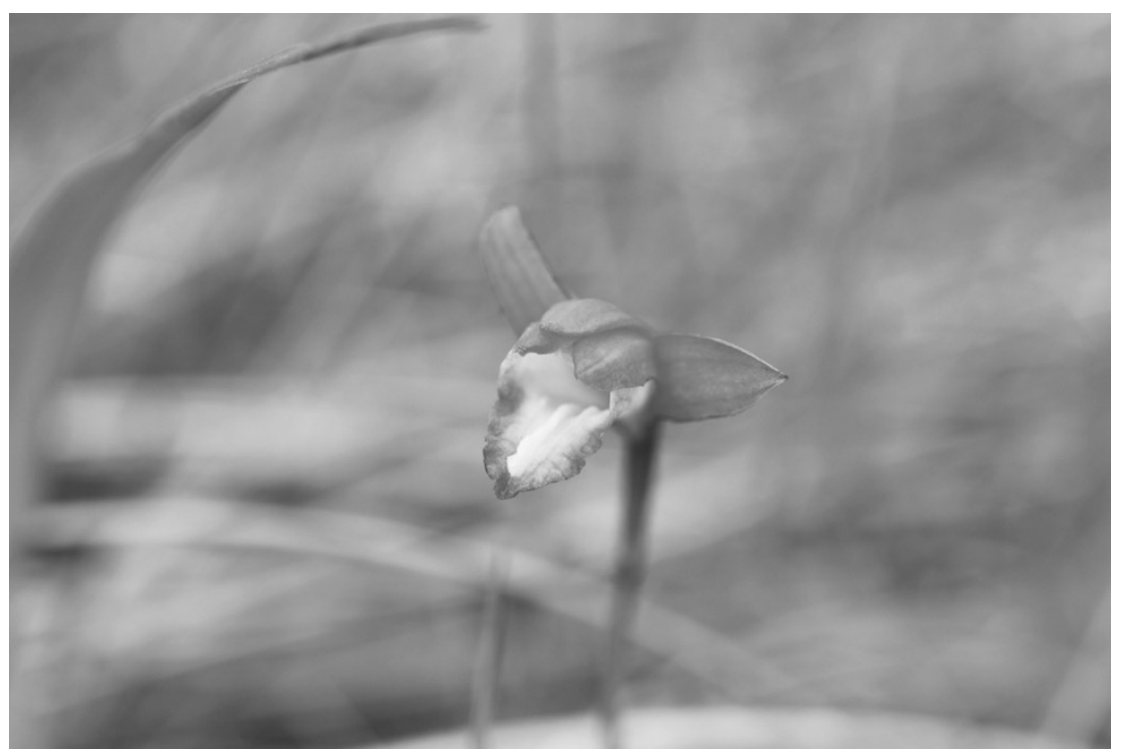

Pис. 7. Pogonia japonica 
как Pinus pumila (Pall.) Regel, Myrica tomentosa, Ledum palustriforme, Ilex sugerokii, I. crenata Thunb., и друrиe.

В травяно-кустарничковом ярусе, преимущественно встречаются Oxycoccus microcarpus, Eriophorum vaginatum, Lysichiton camtschatcense (L.) Schott, Empetrum sibiricum V.Vassil., Hemerocallis esculenta Koidz., некоторые виды мелких Carex sp. и др. Также основной аспект создают зеленые мхи и прежде всего, Dicranum sp., Sphagnum sp.

Краткая таксационная характеристика древесного яруса и фитоценотической структуры представлена в таблицах 1, 2 [3].

Кустарниково-пушицево-осоково-разнотравное сообщество с избыточным увлажнением (Myrica tomentosa+Ilex sugerokii+Ledum palustriforme - Sieversia pentapetala+Drosera anglica+Drosera rotundifolia + Eriophorum vaginatum + Oxycoccus microcarpus+Carex sp.) имеет геогра-

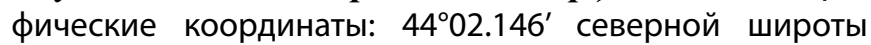
и $145^{\circ} 49.772^{\prime}$ восточной долготы. Высота над уровнем моря составляет 8 м. Размеры описываемой площади 20×20 м (рис. 3).

В данном типе сообщества доминируют Myrica tomentosa (DC.) Aschers. et Graebn, Sieversia pentapetala L., Ledum palustriforme Khokhr. et Maz., Drosera rotundifolia и др.

Характеристика фитоценотической структуры исследуемого фитоценоза представлена в таблице 3. В кустарниковом ярусе доминантом выступает Myrica tomentosa. Травяно-кустарничковый ярус слагает довольно значительное количество видов растений. Наиболее часто встречаются Carex sp, Oxycoccus microcarpus, Sieversia pentapetala, Drosera anglica, Drosera rotundifolia, Menyanthes trifoliate, Utricularia intermedia, Hemerocallis esculenta и др. (рис. 4, 5). Среди мхов, как правило доминируют зеленые мхи Dicranum sp., Sphagnum sp.

На исследуемой территории нами было обнаружено 4 редких вида растений, занесенных в Красные книги РФ и Сахалинской области, такие как Picea glehnii, Iris ensata, Pogonia japonica, Ilex sugerokii (таблица 4) $[6,7]$.

Из приведенного в таблице списка редких растений, 1 вид обладает наиболее высоким охранным статусом - 1 (Е) - Iris ensata, а 3 вида имеют статус рангом ниже 2(V) - Picea glehnii, Ilex sugerokii, статус 3 (R) Pogonia japonica, но также весьма высокий.
Picea glehnii - зимнезеленое дерево, высотой выше 10 м, участвует в сложении древесного яруса елово-кустарниково-разнотравного сообщества, образуя на сильно увлажненных участках криволесье. Iris ensata, Pogonia japonica и Ilex sugerokii (рис. 6, 7) редко встречаются в кустарниково-разнотравном сообществе.

\section{Результаты}

В результате проведенного исследования было выявлено 29 видов растений, из 23 родов, 18 семейств. Описываемые сообщества елово-кустарниково-разнотравное (Picea glehnii - Myrica tomentosa+Ilex sugerokii+Ledum palustriforme - Eriophorum vaginatum + Oxycoccus microcarpus + Carex sp.) и кустарноково-разнотравное сообщество (Myrica tomentosa+Ilex sugerokii+Ledum palustriforme - Sieversia pentapetala + Drosera anglica + Drosera rotundifolia + Eriophorum vaginatum + Oxycoccus microcarpus + Carex sp.) имеют невысокое видовое разнообразие, оно типичное для заболоченных участков и суровых климатических условий. В исследуемых фитоценозах обнаружены популяции редких и охраняемых видов растений (Picea glehnii, Iris ensata, Pogonia japonica, Ilex sugerokii) требующих особого подхода при реализации хозяйственной деятельности, строительных работ на участке.

\section{Обсужмение}

Безусловно, при осуществлении хозяйственных работ, природные комплексы подвергаются негативному воздействию, а порой даже значительному или полному их истреблению. При проведении планируемых работ предполагается полное или частичное уничтожение почвенного и растительного покровов.

Сумма материального ущерба от проектируемых работ будет состоять, в первую очередь из стоимости вырубаемой древесины. Разумеется, при проведении планируемых работ будут вырублены не только деревья, но и уничтожены другие компоненты лесных сообществ.

\section{Зак^ючение}

Для минимизации негативного воздействия на растительные сообщества и окружающую среду в целом, необходимо: строго соблюдать предусмотренные проектом технологию и очередность проводимых работ, а также противопожарные нормы и правила; применять современные природно-щадящие агрегаты и технику; пересадить имеющиеся редкие растения в более безопасные для них участки с учетом их экологических особенностей. 


\section{ЛИТЕРАТУРА}

1. Атлас Курильских островов. Москва - Владивосток, 2009.- 516 с.

2. Баркалов В.Ю. Флора Курильских островов. Владивосток, 2009.- 468 с.

3. Биоразнообразие Сахалинской области: учебное пособие / Я.В. Денисова, И.В. Еременко, Я.П. Белянина и др.— Южно-Сахалинск: изд-во СахГУ, 2012.— $400 \mathrm{c}$.

4. Воробьев Д.П. Растительность Курильских островов. М. 一 Л.: Изд-во АН СССР, 1963.— 92 с.

5. Еременко Н.А., Баркалов В.Ю. Сезонное развитие растений южных Курильских островов: Дальнаука, 2010. — 271 с.

6. Красная книга РСФСР. Растения. М.: Росагропромиздат, 1988. - 592 с.

7. Красная книга Сахалинской области. Растения и грибы. Кемерово, 2019. - 351 c.

8. Мелехов И.С. Лесоведение. М.: Изд-во МГУЛ, 2002. - 488 с.

9. Определитель высших растений Сахалина и Курильских островов. Л.: Наука, 1974. - 372 с.

10. Сосудистые растения Советского Дальнего Востока. Л: Наука, 1985-1996. Т. 1-8.

11. Сукачев В.Н., Зонн С.В. Методические указания к изучению типов леса. М.: Изд-во АН СССР, 1961. - 144 с.

12. Шенников А.П. Введение в геоботанику. Л.: Изд-во ЛГУ, 1964. - 447 с.

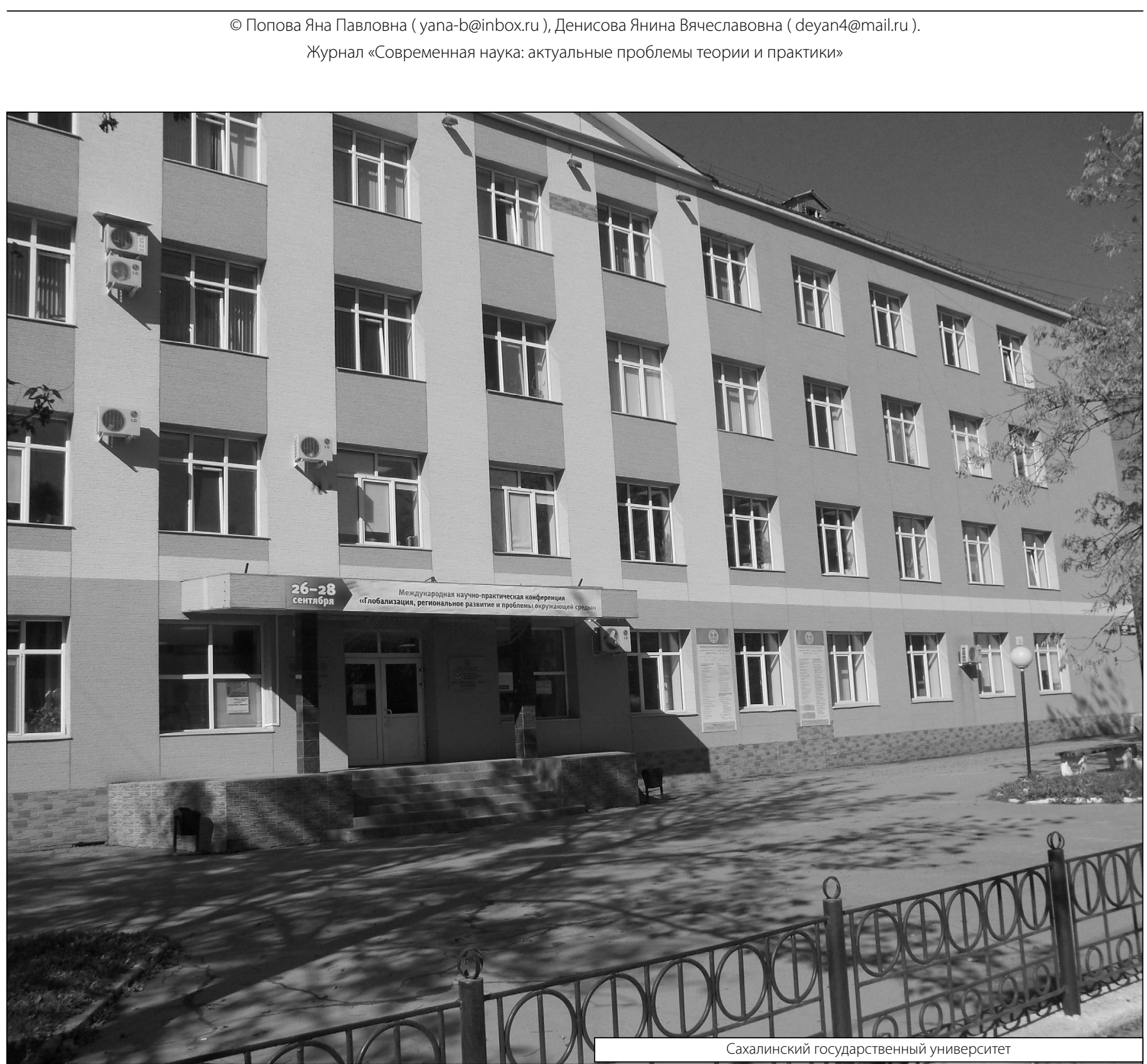

